\title{
Amel Ahmed, Democracy and the Politics of Electoral System Choice: Engineering Electoral Dominance (Cambridge University Press. 2013), 242p, £18.99, ISBN 9781107484139
}

\author{
Qingjie Zeng ${ }^{1}$
}

Published online: 6 April 2016

(C) Fudan University and Springer Science+Business Media Singapore 2016

Amel Ahmed is the Associate Professor of Political Science at the University of Massachusetts Amherst. In her latest book, Democracy and the Politics of Electoral System Choice: Engineering Electoral Dominance, Ahmed examined the reconfiguration of national electoral systems in major western countries during the period of suffrage expansion. Throughout the 19th and early 20th century, political elites in European countries faced mounting public pressure to introduce universal suffrage. At this critical juncture of political transformation, the design of electoral systems came under intense scrutiny. Ahmed argued that a unifying theme behind the flurry of electoral system reform in the West is the attempt to erect "exclusionary safeguards" that would preserve the existing political and economic order. Facing the prospects of extending voting rights to the working class, which constitutes a significant portion if not always the majority of the electorate, the ruling elites took great pains to introduce electoral systems that would minimize the threat posed by socialist parties to the capitalist, liberal-democratic order. Specifically, both the proportional representation (PR) and single-member-plurality (SMP) systems were initially introduced to replace the old majoritarian electoral rule that was feared to facilitate the political dominance of the workers' parties.

Before the age of universal suffrage, political competition in Western countries is typically played out between a Liberal Party representing industrial and middleclass interests and a Conservative Party championing the cause of the landed class. These predemocratic parties were referred to as "right parties," because their ideal points were to the right of the median voter after suffrage expansion. These right parties were deeply anxious that their control of the political scene would be ended

Qingjie Zeng

zqingjie@fudan.edu.cn

1 Fudan University, Shanghai, China 
by extending voting rights to the working class, whose superiority in number could contribute to the electoral success of a worker's party. To preempt the dominance of working-class parties, the right parties pursued a mixed strategy of containment and competition. With containment, the right parties sought to prevent the formation of worker's parties or, if such parties have been formed, dissuade them from adopting radical, revolutionary programs. Strategies of containment include outright repression and accommodative policies to induce working-class support for right parties.

Depending on the success of containment, the right parties would decide how to design electoral systems to minimize the threat from the left. Before suffrage expansion, most Western countries practiced a mix of single-member and multimember districts, the latter emerging from urban districts, where members were added to existing districts in proportion to the growing population. Due to the concentration of workers in urban areas, suffrage expansion could potentially allow working-class parties to sweep all the seats in multimember districts. In this context, both SMP and PR were seen as electoral safeguards serving right parties' interests. SMP would open up the game of redistricting that favored the ruling right parties, while PR's low threshold for entry would guarantee the right party's competitiveness and make it more difficult for working-class parties to achieve majority status.

The choice between SMP and PR crucially depends on the nature of the workingclass threat, which can be measured along two dimensions: the worker's parties' electoral viability and their levels of ideological radicalism. In Ahmed's theoretical framework, the interaction between working-class threat and electoral system choice falls into one of four scenarios. First, when containment strategy succeeded in preventing the formation of strong working-class party, the right parties tended to choose SMP that offered moderate protection against potential socialist threat. Second, working-class parties became electorally viable, but maintained a moderate ideological position. In this case, the right parties would also opt for SMP, because PR's low threshold for entry was likely to encourage the rise of more radical workers' parties. Third, when working-class parties achieved electoral viability with a mix of moderate and radical elements, it became very difficult for the right parties to assess the threat and decide on the optical strategy. These cases, therefore, tend to display a great deal of instability in the choice of electoral systems. As a general rule, SMP would be adopted when worker's movement was more successfully coopted by the right parties, whereas PR would be the preferred option when the measures of accommodation met with total failure. Finally, once working-class parties became both electorally viable and ideologically radical, right parties would cooperate to establish PR to preserve their own competitiveness and prevent a working party majority. This collaboration shows that, when working class mobilization posed an existential threat to the capitalist society, the right parties could set aside narrow partisan interests to serve class interests.

Ahmed tested her logic of electoral system choice against empirical data at three levels of analysis. She first surveyed 18 major Western countries to examine whether there is a correspondence between the success of containment and the electoral system adopted. The cross-national analysis confirmed her hypothesis that the right parties' strategy of competition reflects the magnitude of socialist threat. In countries where the working-class party was either electorally weak (the US, 
Canada) or ideologically moderate (the UK, Australia, New Zealand), the right parties chose SMP to offer moderate protection against socialist threat. When the workers' parties were electorally viable but embraced mixed ideological platforms (France, Italy, Spain), the choice of electoral system displayed a great deal of instability as right parties alternated between different strategies. In the final scenario, an electorally competitive working-class party characterized by ideological radicalism would force right parties to adopt PR (Germany, Austria, Belgium, etc.).

Ahmed then continued to explore four in-depth case studies to further elucidate the causal mechanism at work in each of the four scenarios. The four countries, the US, the UK, France, and Belgium, were chosen due to their great influence throughout the democratic world. The detailed process-tracing in the four countries also allowed Ahmed to illustrate the dynamics of containment and competition within cases. In France, for example, as socialist threat increased after WWI, PR was adopted for establishing stronger safeguards. However, when PR was afterward seen as further radicalizing the workers' movement, SMP was restored in 1927.

Ahmed contends that her interpretation of historical events has major implications for how we understand the nature of the democratization process. The conventional wisdom, characterized by a teleological, deterministic perspective, views democratization as a process that moves gradually toward more inclusiveness. Although the process might be riddled with reactionary measures to restrict participation and competitiveness, successive waves of reforms will eventually remove these barriers to usher in an inclusive polity. Ahmed criticized this view for its failure to appreciate the full significance of the exclusionary safeguards. These safeguards, which stacked the deck in favor of the elites in power prior to the democratization process, have not been removed to pave way for an inclusive polity. Instead, they have become a permanent part of democratic regimes. In other words, the prevailing liberal democratic order in today's world cannot be seen as the culmination of a progressive process; rather, it results from a prolonged struggle of ideas that might have marginalized more radical visions of politics.

Overall, this is a very high-quality book that draws upon a large body of material to shed light on one of the most important topics in political science-the nature of democratization. The breadth of knowledge commanded by the author allowed her to identify a causal mechanism that manifested itself across a large number of cases. The theoretical framework that centered on the right parties' strategy of containment and competition imposed order and structure on what appeared to be a chaotic process that unfolded in multiple countries. The focus on exclusionary safeguards erected by predemocratic elites during early waves of democratization reminds us that the use of electoral manipulation to skew the playing field against opposition is anything but a modern innovation.

Meanwhile, a careful reading of the book also leaves the impression that, on several occasions, there appears to be a disconnect between the book's elegant theoretical arguments and the evidence presented to support them. Most damaging for the book's central claim is the fact that not all political debates regarding electoral system reform seemed to have revolved around the issue of fending off working-class threat. For instance, PR was supported by some state and federal 
legislators in the US as a measure of minority protection, but, contrary to what Ahmed tried to argue, very few advocates of PR mentioned the specific threat of worker mobilization. ${ }^{1}$ It seems wrong to assume that whoever argued against a majoritarian electoral design was necessarily concerned about socialist threat. The same thing can be said about the push for PR in the UK during the $1880 \mathrm{~s}^{2}$ and in France during the 1900s. ${ }^{3}$ Thus, the author might be guilty of overstretching or selectively using data to fit her thesis.

One way in which the author could have made her argument more persuasive is to further elaborate how the right parties perceived the potential threat of the working class. In the Belgian case, the ruling Catholic Party allegedly adopted PR to "provide a better safeguard against an overwhelming socialist victory," ${ }^{4}$ although in the previous election, the Catholics obtained 110 seats against the Socialist's 28. Moreover, in the three consecutive elections prior to PR reform, the Socialist Party made no gain at all in its seat share. Why would a ruling party enjoying such electoral dominance be so concerned about the challenge of a minority party? Was there any other factor that prompted the electoral system reform? More elaboration on this issue would help convince the readers that electoral system choice was mainly motivated by the fear of a Socialist takeover.

There are some other areas where more discussion and clarification is needed to strengthen the author's claim. First, the author argued that SMP is considered an electoral safeguard partly, because it facilitates gerrymandering. The right parties, however, could also have pursued redistricting efforts under the old mix of singlemember and multiple-member districts. Is gerrymandering easier to manage or politically less contentious under SMP than under the old ad hoc electoral system? Second, in the book's rather concise conclusion chapter, the author would be helped by clarifying her claim that "the safeguards...have become a permanent part of these democratic regimes... relegating radical visions to the margins of democratic politics." 5 How do we test the claim that these safeguards have become permanent? If the criterion for evaluating the existence of exclusionary safeguards is the perennial minority status of working-class parties, then such safeguards seemed to have been overcome in many countries. Moreover, what exactly are the "radical visions" of democratic politics?

Finally, the author questioned the view that Western countries have moved gradually toward more inclusive democratic systems. Indeed, she argues that the exclusionary safeguards established by early democratizing countries were comparable to the "menu of manipulation" in contemporary electoral authoritarian regimes (Schedler 2002). While the boundary between electoral system design and outright electoral manipulation can be fuzzy at times, the former usually does not undermine the free and fair quality of elections. Electoral manipulation, on the other hand, includes a variety of illegitimate measures, such as ballot stuffing, selective

\footnotetext{
${ }^{1}$ Pp. 104-7.

${ }^{2}$ Pp. $132-5$.

${ }^{3}$ Pp. 155-6.

${ }^{4}$ Pp. 180.

5 p. 193.
} 
disenfranchisement, and violent repression. The author should have given more attention to this important distinction when drawing parallel between early democratizers and the third wave democracies.

In conclusion, Ahmed's book made important contribution to our understanding of the historical process of democratization. Scholars who study contemporary emerging democracies and electoral authoritarian regimes will also benefit enormously from the strategic choice of electoral system in the 19th century European countries.

\section{Reference}

Schedler, Andreas. 2002. The menu of manipulation. Journal of Democracy 13(2): 36-50. 